\title{
Acoustic Control Method of Quality Characteristics of New Transformer Oil
}

\author{
Anastasiia V. Krekhova, \\ Yuriy N. Bezborodov* and Andrey P. Batrak \\ Siberian Federal University \\ 79 Svobodny, Krasnoyarsk, 660041, Russia
}

Received 26.02.2019, received in revised form 18.05.2019, accepted 19.06.2019

Power transformers are the most expensive and strategically important components of any power generation and transmission system. Diagnostics methods result from the necessity to provide the operational reliability of power equipment and extend its operation time. Acoustic method is one of the perspective methods to determine transformer oil quality. In comparison with standard methods the acoustic method have follow important advantages: low labor intensity, need lack of the difficult expensive equipment, carrying out researches in vitro frames and high qualification of researches.

This study represents results of impurity influence investigation (water and cellulose) on an acoustic range of new transformer oil.

Keywords: power transformer, transformer oil, acoustic method, acoustic research, insulation.

Citation: Krekhova A.V., Bezborodov Yu.N., Batrak A.P. Acoustic control method of quality characteristics of new transformer oil, J. Sib. Fed. Univ. Eng. technol., 2019, 12(6), 746-752. DOI: 10.17516/1999-494X-0174.

\section{Метод акустического контроля \\ качественных характеристик \\ товарного трансформаторного масла}

\section{А.В. Крехова, Ю.Н. Безбородов, А.П. Батрак \\ Сибирский федеральный университет \\ Россия, 660041, Красноярск, пр. Свободныий, 79}

Силовые трансформаторы одни из самых дорогих и стратегически важных компонентов любой энергосистемы. Для обеспечения надежности работы энергетического оборудования и увеличения их срока службы требуются методы диагностики. Акустический метод контроля

(C) Siberian Federal University. All rights reserved

This work is licensed under a Creative Commons Attribution-NonCommercial 4.0 International License (CC BY-NC 4.0).

* Corresponding author E-mail address: inig@sfu-kras.ru, labsm@mail.ru 
Anastasiia V. Krekhova, Yuriy N. Bezborodov... Acoustic Control Method of Quality Characteristics of New Transformer...

является одним из перспективных методов по определению качества трансформаторного масла. По сравнению со стандартными методами акустический метод обладает рядом существенных преимуществ: низкая трудоемкость, отсутствие необходимости применения сложного дорогостоящего оборудования, проведения исследований в лабораторных условиях и высокой квалификации персонала, проводящего контроль.

Данная статья представляет результаты исследования влияния примеси (воды и целлюлозы) на акустический спектр товарного трансформаторного масла.

Ключевые слова: силовой трансформатор, трансформаторное масло, акустический метод, акустическое исследование, изоляиия.

\section{Introduction}

Large transformer was the most important and expensive part in a power system and they were considered to be reliable components of electrical stations if their design life is 20-35 years (increasing to 50 years in practice with appropriate maintenance) $[1,2]$.

Transformer oil provided operability of all system. Therefore, it was not surprising, that the questions of new transformer oil quality, its control and diagnostics were relevant. Among a set of qualitative oil characteristics [3], the water and mechanical impurity content were important.

The importance of water presence in paper-oil systems had been recognized since the 1920s. Pure transformer oil consisted of saturated hydrocarbons such as paraffins and naphthenes. Because of their nonpolar molecule structure, pure oil could dissolve only a very small quantity of water dispersed as water vapour according to Henry's law [4].

Water was known to play a role of an ageing process catalyst insulation and caused three dangerous effects: it decreases the dielectric withstand strength, accelerates cellulose aging, and causes the emission of bubbles at high temperatures. The knowledge about the actual moisture concentration was required to control transformer oil condition and quality.

Various mechanical impurities could be in new transformer oil in the course of its production.

The existing moisture (the Karl Fischer titration [4], equilibrium diagrams [5, 6], method of polarization and depolarization currents (PDC) [7], dielectric methods [8, 9], chromatographic method [10-12], GOST 7822-75 [13], RD 34.43.107-95 [14]) and mechanical impurities (Fourier transform infrared (FTIR) and near-infrared (NIR) spectroscopy [15], GOST 6370-83 [16]) definition methods had a number of essential shortcomings.

We proposed to use the acoustic method to determine these impurities and their influence on transformer oil condition. The scientific idea is to measure acoustic signals generated by impurities (water and cellulose as a mechanical impurity) in transformer oil and to analyse their frequency spectrum to acquire the information about transformer oil condition.

\section{Materials and methods}

Fig. 1 represented the measurement setup which consisted of a frequency generator, amplifier, transformer tank filled with electro-insulating oil and impurities, two electro-mechanical (piezoelectric) transducers (emitter and receiver), preamplifier, level detector, microcontroller and a personal computer (PC) with designed software. 


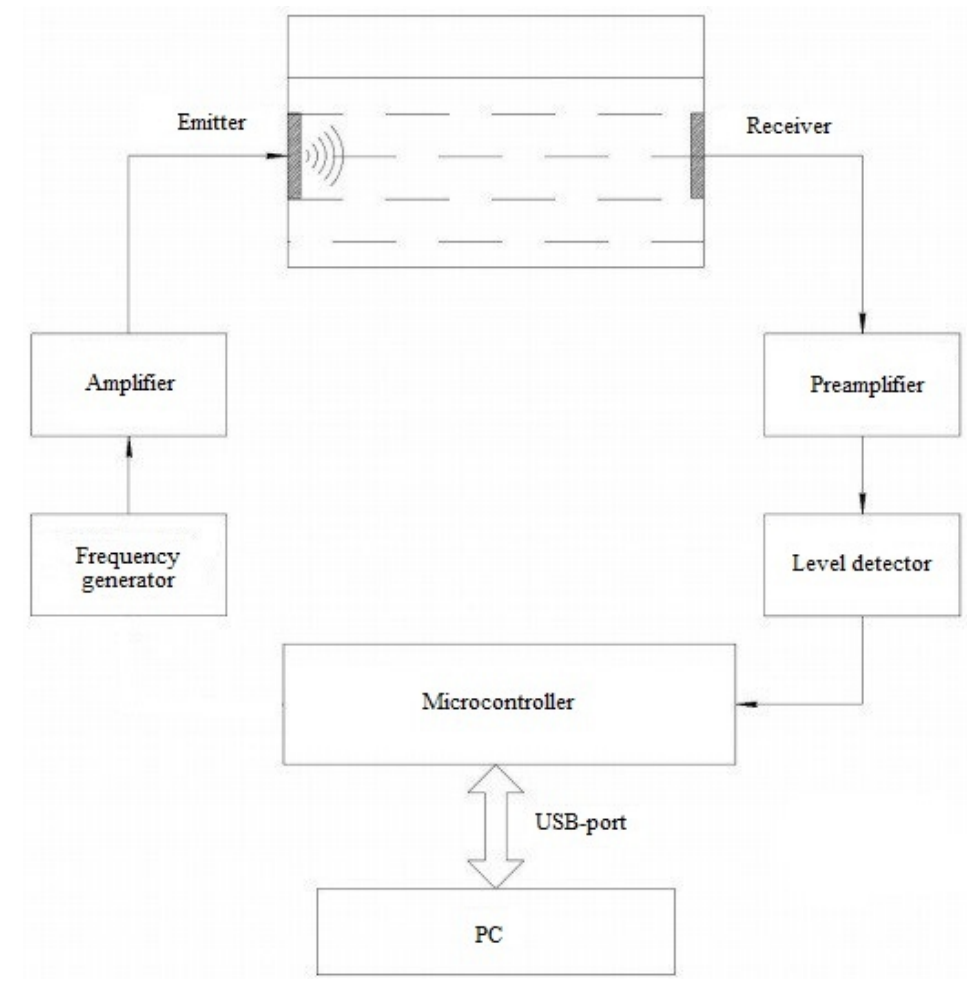

Fig. 1. Measurement setup

As the studied sample the transformer oil of T-1500 brands was applied. The acoustic signals of both oils were studied in $1-10 \mathrm{kHz}$ frequency range at room temperature $\left(25^{\circ} \mathrm{C}\right)$.

To determine the effect of water and cellulose on transformer oil condition, we added the impurities to different samples of new oil and measured acoustic signals.

Water was added to the first transformer oil sample with a pipette. The mixture was weighed. Sound wave power was measured in 4 points, where percentage scale of water mass concentration in transformer oil was $0 \%, 0,0994 \%, 0,224 \%, 0,355 \%$. This range was chosen in view of oil hygroscopicity. Measurement error did not exceed 0,0005 g. [17]

Similarly, cellulose were added cellulose to the second transformer oil sample. The sound wave power values were measured, with cellulose mass concentration in transformer oil being $0 \%, 0,06 \%$, $0,18 \%, 0,31 \%$ [18].

The processing technique the obtained experimental data included the following main stages:

1. Determination of the impurity influence importance on an acoustic range of transformer oil;

2. Determination of the water and cellulose importance influence on an acoustic range of transformer oil;

3. Definition of correlation coefficients;

4. Choice of the bearing frequencies which were responsible for the content of impurities in transformer oil;

5. Formation of the regression equations for the bearing frequencies;

6. Adequacy testing of the received models. 


\section{Results}

The comparison test showed that the AE signals measured in the samples of new and aged transformer oils were significantly different (see Fig. 2).

The importance of the impurity influence on acoustic range of transformer oil was confirmed by means of Student's aneurysm t-test with the $95 \%$ confidential probability.

The effect of water and cellulose content were determined applying the Student's aneurysm t-test. As a result, water and cellulose influenced transformer oil quality.

Applying the regression procedure the $2 \mathrm{kHz}$ frequency was studied to obtain a correlation between the sound wave power and water content in oil. The correlation coefficient value were $-0,96$. Therefore, the dependence between the sound wave power and water in the range from 0 to $0,335 \%$ was established as linear which had type:

$$
\mathrm{Y}=\mathrm{b}_{0}+\mathrm{b}_{1} \mathrm{X}
$$

Determining the regression coefficients, for the $2 \mathrm{kHz}$ the following equation was obtained:

$$
\mathrm{Y}_{2 \mathrm{kHz}}=10,1 \cdot 10^{-9}-2,83 \cdot 10^{-8} \cdot \mathrm{X}
$$

Similarly, the $4 \mathrm{kHz}$ frequency was studied as bearing frequency to obtain a linear dependence between the sound wave power and cellulose content in oil. The correlation coefficient value were 0,94 . Determining the regression coefficients, for the $4 \mathrm{kHz}$ the following equation was obtained

$$
\mathrm{Y}_{4 \mathrm{kHz}}=5,99 \cdot 10^{-9}+3,22 \cdot 10^{-8} \cdot \mathrm{X}
$$

Fig. 3a represented modal and experimental dependences between sound wave power and water content for the $2 \mathrm{kHz}$ frequency [19]. Fig. $3 \mathrm{~b}$ represented modal and experimental dependences between sound wave power and cellulose content for the $4 \mathrm{kHz}$ frequency.

The received models unfermented adequacy testing according to the Phisher's criterion.

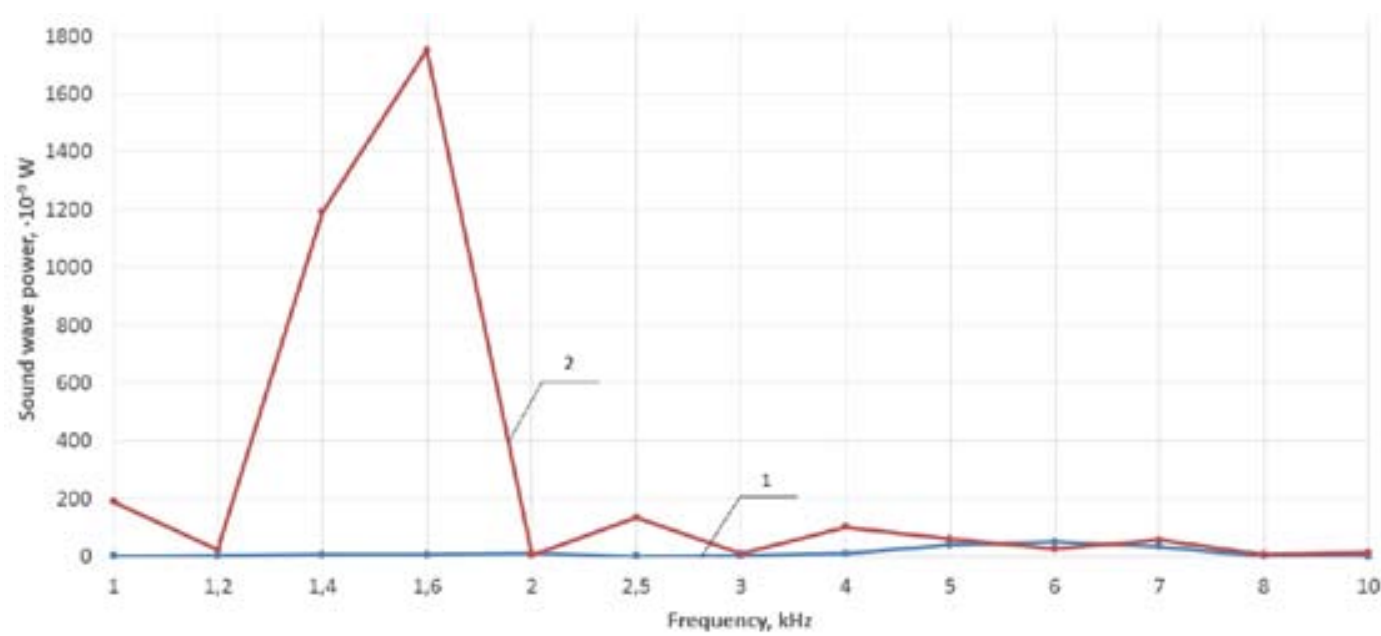

Fig. 2. Response characteristics of a new and aged transformer oils: 1 - new transformer oil, 2 - aged transformer oil 


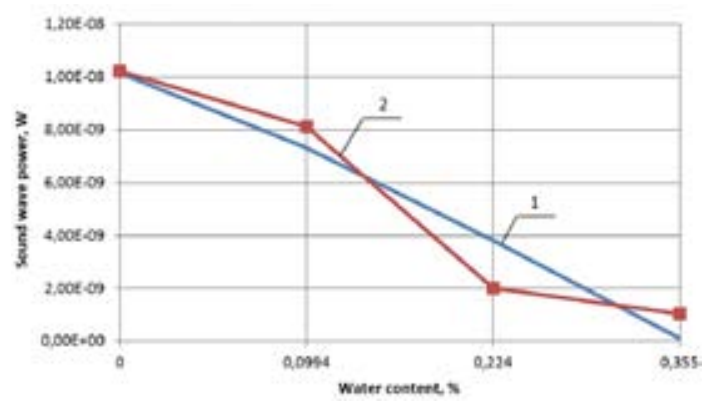

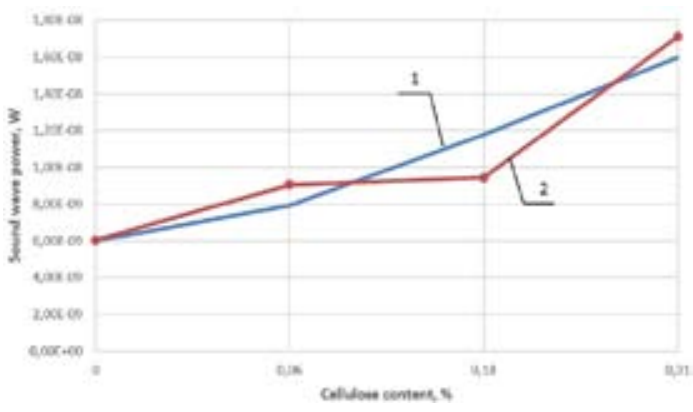

b

Fig. 3. Comparison of model and experimental dependences between sound wave power and a - water content for $2 \mathrm{kHz}$ frequency; $\mathrm{b}$ - cellulose content for $4 \mathrm{kHz}$ frequency 1 - model dependence; 2 - experimental dependence

\section{Conclusion}

Water and cellulose were determined as the main reasons of transformer oil degradation. This paper considered various methods used to determine the impact of the impurities. The acoustic method was highlighted as the most perspective method for diagnostics of transformer oil condition. A detailed explanation of the experiments with new transformer oil was presented.

Compared to other methods, the acoustic method had a number of advantages. For example, its possibility to determine the content of several impurities applying the same equipment in field, e.g. in a substation or in a power station. Therefore, this method is available for complex diagnostics. Compared to other methods it is simpler, cheaper, less time-consuming as we do not need to transport oil samples to an equipped laboratory, use sophisticated reagents, and skills. These advantages allow conducting researches with fulfilled transformer oil.

\section{References}

[1] Kurtz C., Ford G., Vainberg M., Lebow M., Ward B. Managing aged transformers, Transmission \& Distribution World, 2005, 36-45.

[2] Metwally I.A. Failures, monitoring, and new trends of power transformers. IEEE potentials, 2011, May/June, 36-43.

[3] Батрак А.П., Тюрюмина А.В., Никитина А.В. Сравнение качественных характеристик трансформаторных масел. Тяжелое машиностроение, 2013, 3, 41-44 [Batrak A.P., Tyuryumina A.V., Nikitina A.V. The comparison of transformer oil quality characteristics, Heavy equipment industry, 2013, 3, 41-44 (In Russian)].

[4] Koch M., Tenbohlen S., Blennow J., Hoehlein I. Reliability and improvements of water titration by the Karl Fischer technique, 15th ISH, Ljubljana, 2007.

[5] Fabre J., Pichon A. Processes and products of paper in oil. Application to transformers. International Conference on Large High Voltage Electric System (CIGRE), Paris, 1960, 137.

[6] Oommen T.V. Moisture equilibrium in paper-oil systems, Electrical/Electronics Insulation Conference. Chicago,1983, 162-166. 
[7] Leibfried T., Kachler A.J. Insulation diagnostics on power transformers using the Polarization and Depolarization current (PDC) analysis, IEEE International Symposium on Electrical Insulation. Boston, 2002, 170-173.

[8] Koch M., Krüger M. A fast and reliable dielectric diagnostic method to determine moisture in power transformers, International Conference on Condition Monitoring and Diagnosis. Beijing, 2008, 467-470.

[9] Gradnik T., Konkan-Gradnik M. , Petric N., Muc N. Experimental evaluation of water content determination in transformer oil by moisture sensor, IEEE International Conference on Dielectric Liquids. Trondheim, 2011, 1-4.

[10] Бузаев В.В. Роль физико-химических методов анализа в системе оценки состояния трансформаторного оборудования. Тр. науч.-практ. семинара по проблеме диагностики электрической изоляиии. Новосибирск, 2004 [Buzayev V.V. A role of the physical and chemical analysis methods in the assessment system of the transformer equipment condition, A scientific and practical seminar on a problem of diagnostics of electric isolation, Novosibirsk, 2004 (In Russian)].

[11] Чупак Т.М. Прогнозирование технического состояния силовых маслонаполненных трансформаторов, автореф. дис. ... канд. техн. наук. Красноярск, 2007, 20 с. [Chupak T. М. of Technical condition forecasting of power oil-filled transformers, Thesis ... cand. of tech. Sci. Krasnoyarsk, 2007, 20 p. (In Russian)].

[12] Давиденко И.В. Разработка системы многоаспектной оиенки технического состояния и обслуживания высоковольтного маслонаполненного электрооборудования, автореф. дис. ... канд. техн. наук. Екатеринбург, 2009. 46 с. [Davidenko I.V. Development of the multidimensional assessment system of technical condition and service of high-voltage oil-filled electric equipment, Thesis ... cand. of tech. Sci. Yekaterinburg, 2009, 20 p. (In Russian)].

[13] ГОСТ 7822-75. Масла нефтяные. Метод определения растворенной воды. [Электронный pecypc] - Режим доступа:_http://docs.cntd.ru/document/1200004512 - Заглавие с экрана. [GOST 7822-75Petroleum oils. Method of dissolved water determination [Electronic resource] - Access: http://docs.cntd.ru/document/1200004512.

[14] РД 34.43.107-95. Методические указания по определению содержания воды и воздуха в трансформаторном масле. [Электронный ресурс] - Режим доступа: https://files.stroyinf.ru/ Index2/1/4294844/4294844653.htm - Заглавие с экрана. [RD 34.43.107-95. Procedural Guidelines for the Determination of Content of Water and Air in Transformer Oil [Electronic resource] - Access: https://files.stroyinf.ru/Index2/1/4294844/4294844653.htm.

[15] Ali M., Emsley A.M., Herman H., Heywood R.J. Spectroscopic studies of the ageing of cellulosic paper. Polymer, 2001, 42, 2893-2900.

[16] ГОСТ 6370-2018. Нефть, нефтепродукты и присадки. Метод определения механических примесей. [Электронный ресурс] - Режим доступа: http://docs.cntd.ru/document/1200160609 Заглавие с экрана. [Petroleum, petroleum products and additives. Method for determination of mechanical admixtures [Electronic resource] - Access: http://docs.cntd.ru/document/1200160609.

[17] Батрак А.П., Чупак Т.М., Тюрюмина А.В., Никитина А.В. Акустический анализ свойств трансформаторных масел. Тяжелое машиностроение. 2014, 4-5, 45-46. [Batrak A.P., Tyuryumina A.V., Nikitina A.V. The acoustic analysis of transformer oil properties, Heavy equipment industry, 2014, 4-5, 45-46 (In Russian)]. 
[18] Тюрюмина А.В., Секацкий В.С., Батрак А.П. Применение метода акустической эмиссии для диагностики силовых трансформаторов. Завалишинские чтения, Санкт-Петербург, 2017, 293-296 [Tyuryumina A.V., Sekackiy V.S., Batrak A.P. Use of acoustic emission method for power transformer diagnostics, Zavalishin's Readings, Saint-Petersburg, 2017, 293-296 (In Russian)]

[19] Anastasiya Tyuryumina, Andrey Batrak and Victor Sekackiy. Determination of transformer oil quality by the acoustic method. MATEC Web of Conferences. 2017, 113. 